as media through which we may imbue the mind with certain general and abstract ideas. If called upon to define the scientific spirit, I should say that it was the love of truth for its own sake. This definition carries with it the idea of a love of exactitude--the more exact we are the nearer we are to the truth. It carries with it a certain independence of authority ; because, although an adherence to authoritative propositions taught us by our ancestors, and which we regard as true, may, in a certain sense, be regarded as a love of truth, yet it ought rather to be called a love of these propositions, irrespective of their truth. The lover of truth is ready to reject every previous opinion the moment he sees reason to doubt its exactness. This particular direction of the love of truth will lead its possessor to pursue truth in every direction, and especially to investigate those problems of society where the greatest additions to knowledge may be hoped for.

Scientific method we may define as simply generalised common sense. I believe it was described by Clifford as organised common sense. It differs from the method adopted by the man of business, to decide upon the best method of conducting his affairs, only in being founded on a more refined analysis of the conditions of the problem. Its necessity arises from the fact that, when men apply their powers of reason and judgment to problems above those of every-day life, they are prone to lose that sobriety of judgment and that grasp upon the conditions of the case which they show in the conduct of their own private affairs. Business offers us an example of the most effectual elimination of the unfit and of "the survival of the fittest." The man who acts upon false theories loses his money, drops out of society, and is no longer a factor in the result. But there is no such method of elimination when the interests of society at large are considered. The ignorant theoriser and speculator can continue writing long after his theories have been proved groundless, and, in any case, the question whether he is right or wrong is only one of opinion.

I ask leave to introduce an illustration of the possibilities of scientific method in the direction alluded to. Looking at the present state of knowledge, of the laws of wealth and prosperity of communities, we see a great resemblance to the scientific ideas entertained by mankind at large many centuries ago. There is the same lack of precise ideas, the same countless differences of opinion, the same mass of meaningless speculation, and the same ignorance of how to analyse the problem before us in the two cases. Two or three centuries ago the modern method of investigating nature was illustrated by Galileo, generalised by Bacon, and perfected by Newton and his contemporaries. A few fundamental ideas gained, a vast load of useless rubbish thrown away, and a little knowledge how to go to work acquired, have put a new face upon society. Look at such qucstions as those of the tariff and currency. It is impossible not to feel the need of some revolution of the same kind which shall lead to certain knowledge of the subject. The enormous difference of opinion which prevails shows that certain knowledge is not reached by the majority, if it is by any. We find no fundamental principles on which there is a general agreement. From what point must we view the problem in order to see our way to its solution?

I reply, from the scientific standpoint. All such political questions as those of the tariff and the currency are, in their nature, scientific questions. They are not matters of sentiment or feeling which can be decided by popular vote, but questions of fact, as effected by the mutual action and interaction of a complicated series of causes. The only way to get at the truth is to analyse these causes into their component elements, and see in what manner each acts by itself, and how that action is modified by the presence of the others: in other words, we must do what Galileo and Newton did to arrive at the truths of Nature. With this object in view, whatever our views of culture, we may let science, scientific method, and the scientific spirit be the fundamental object in every scheme of a liberal education.

S. NEWCOMB

\section{THE KRAKATOA ERUPTION}

T $\mathrm{HE}$ inquiry, instituted in consequence of a Government resolution of October 4,1883 , into the nature, the extent, and the consequences of the volcanic eruptions of Krakatoa, has led to various remarkable results of which a short account is given here. A detailed report is in course of preparation, but will not appear for some months, as the making of numerous illustrative maps and plates will take much time. The inquiry did not extend solely to the islands of the Straits of Sunda, but also to the coast countries of the Lampong districts, Bantam and Batavia, which were partly or entirely destroyed. In the Straits of Sunda the islands of Merak, Toppershoedje, Dwars in den Weg (Thwart the Way), Seboekoe, Sebesi, Lagoendi, Krakatoa, Taboean, Prince's Island, the Monnikrotsen (the Monk's Rocks), and Meeuwen Island (Mew's Island), were visited; further, the coast strip from Ketimbang to Kalianda, and inland as far as Kesoegihan, besides the foot of the Radja Bassa; the coast of Hoeroen to Telok Betong, and the environs of the capital; the southern part of Semangka Bay (the northern part was inaccessible through pumice-stone), the kampocngs Tampang and Elimbing, near the Vlakken Hoek, Java's First Point (Java Head), and the coasts of Tjiringin and Anjer to Merak. The voyage, which lasted seventeen days, was made by the hopperbarge (small steamer) Kediri, commander 't Hoen, given for the inquiry by the temporary chief of the Batavian Harbour Works. About the causes of eruptions there is usually not much to be said, yet in this case something has been ascertained. Krakatoa, namely, lies with a few other volcanoes on a rent or fissure in the crust of the earth which runs across the Straits of Sunda, and of which I indicated the probable existence for the first time three years ago. Along such a fissure little shiftings of the earth's crust are possible, by which a pressure is exercised upon the molten substarces below the crust. It is also possible that along such a rent--however tightly closed by the neighbouring stone-layers-the water may more easily than elscwhere flow to the regions under the earth. If this water comes in contact with the molten substances, steam at high temperature and high pressure is formed, and this steam may be considered as the chief motor of most, if not all, volcanic eruptions.

Many circumstances, therefore, combine to make eruptions take place in preference near fissures, provided water (either rain or sea-water) can penetrate in sufficient quantity. We must conclude from the' 2 co years' quietude of the volcanoes in the Straits of Sunda that the water affuence during that time was but small, and only became larger within the last years. Now it happens that during the last years a great many earthquakes took place along this fissure, of which the lighthouse on "Java's First Point" in particular suffered greatly. The most violent earthquake took place September I, I 880 ; the upper part of the tower was rent, and had to be broken off afterwards. These earthquakes were probably the result of subterranean subsidences, and I think I may assume that through those subsidences modifications took place along the fissure through which the sea-water could ooze in greater quantity than before. Within the three last years the pressure of the steam formed became sufficiently strong to force the lava, out of the much deeper-lying lava strata, upwards through the crater of Krakatoa, and the eruption took place when, at last, the violence of the steam was enabled to force its way through the lava to the crater and the surface. The steam carried with it a ${ }^{1}$ Translation of a Short Report on the Eruption of Krakatoa on August 26, 27 , and 28,1883 . 
quantity of lava, which was mostly shot as fine dust out of the crater. The porous nature of the ejected substances -pumice-stone was almost the only substance formed-is doubtless to be ascribed to the steam, which was blown with great force through the lava. I must keep the more detailed description of the way in which the eruption proper was prepared and took place for a future time, as drawings are requisite for a right understanding of the matter. I must still observe here, however, that through the Krakatoa eruption our notions about the shape and extent of subterranean regions will probably be much modified. If it may be assumed that there exists a connection between our eruptions, the heightened activity of the volcanoes in the Indian Archipelago since that time, and the earthquakes in Australia which took place simultaneously with and succeeded the eruptions of the last days--in any case a remarkable coincidence -then much larger dimensions will have to be allowed to those regions than the present geologists are accustomed to assign to them.

Krakatoa is the only point which has been active. There are reports that Sebesi and the Radja Bassa have also shown activity, but this is inaccurate.

Of the old Krakatoa there is no detailed survey; the English and Dutch sea-charts, both on a small scale, besides a couple of sketches taken by Buijskes in 1849 , and by me in 1880, alone give some idea of the surfaceformation of the island. From the two sketches may be seen that the island had three tops-the northern, called Perboewatan (in some reports Roewatan), was the lowest of the three, and showed streams of lava on various sides ; this is the point which first began to be active in May I 883 , and which probably also ejected pumice-stone in 1860. The centre top bore the name of Danan, and was active also in August 1883. The southern peak, the mountain Rakata properly speaking (which was corrupted into Krakatoa), was by far the highest point of the whole island, and, according to the sea-chart, 822 metres high. This point is also an old crater, but was not active in 1883 .

On May 20, 1883 , the Perboewatan began suddenly to show signs of activity; that nothing was known before then of an approaching eruption must be ascribed to the fact that Krakatoa was uninhabited, and only visited occasionally by Lampong fishermen, who went no further than the coast. Otherwise it would seem inexplicable that no previous signs of it should have been noticed. The eruptions lasted with various degrees of violence, and with intervals, till August 26; while latterly also the crater of Mount Danan became active. Though in themselves not unimportant, these eruptions were insignificant compared to what followed. On August II trees were still growing on the peak, so that the destruction of vegetable life was then still limited to the immediate neighbourhood of the craters. On the 26th the explosions much increased in violence, and they reached their maximum on the $27^{\text {th }}$, at Io a.m. They then diminished in strength, but lasted still the whole night of Monday to Tuesday, till they suddenly ceased on the $28 \mathrm{th}$, at about 6 a.m.

About the eruptions from May till August 26 little of importance has, on the whole, become known; all I have been able to collect will be mentioned in the detailed report.

The eruptions of August 26 and 27 were accompanied by violent detonations and air vibrations. During those days almost incessantly a rumbling sound was heard which resembled the noise of thunder at a distance, the explosions properly speaking were accompanied by short detonations which can best be compared to heavy cannon shots, but the most violent detonations were still shorter and more rattling, and cannot be compared to any other sound.

The sounds of the explosions in May were heard in a north-west direction at Moeara Doea in Palembang, and at Bintoehan, in the division of Kauer in Benkoelen, respectively 230 and 270 kilometres from Krakatoa; the transmission of the sound on August 27 surpasses, how ever, all which is known of the kind. The explosions were heard in Ceylon, in Burmah, at Manilla, at Doreh in the Geelvink Bay (New Guinea), and at Perth on the west coast of Australia, besides all the places which lie closer to Krakatoa than the above-mentioned. If a circle is drawn from Krakatoa with a radius of $30^{\circ}, 1,800$ geographical miles, or 3,333 kilometres, the circle will go exactly over the furthest points where the sound was heard. The furthest distance between the points east and west where the sound was heard is therefore $60^{\circ}$ (the diameter of the circle) or one-sixth of the whole circumference of the earth. The surface of this circle, or rather of the spherical segment, comprises more than one-fifteenth of the surface of the earth. In historic times no eruption is known of which the sound was transmitted over such an enormous area. At the eruption of Tombora in Sumbawa, in $181_{5}$, the radius of the circle within which the sound was heard, was but half the size, namely $15^{\circ}$, the surface being therefore 3.93 times smaller.

If a circle with the same radius, namely $30^{\circ}$, is drawn round the earth, taking Amsterdam as the centre, the circle would have the following course. The northern point lies $82^{\circ}$ north latitude, thus north of Spitzbergen ; from there the circle runs to the middle of Novya Zemlya, thence along the Ural Mountains to Orenburg, Tiflis, Damascus, Jerusalem, Suez; crosses the Tropic of Cancer at about $15^{\circ}$ east longitude from Greenwich, reaches the most southern point at $22^{\circ}$ north latitude in the Desert of Sahara, crosses the Tropic of Cancer once more at $5^{\circ}$ west longitude from Greenwich, runs close along Ferro, includes the Canary Islands and Azores, besides the greater part of Greenland, and runs back to the starting point north of Spitzbergen. In various places it was observed that the strongest detonations were heard at different hours, and also that in places in the neighbourhood of Krakatoa little or nothing was heard of the sound, whereas it was heard very distinctly in places further removed. Thus for example the loudest report was heard at Buitenzorg at a quarter to seven, at Batavia at half-past eight, at Telok Betong at ten o'clock on the morning of the 27 th. This was caused principally by the direction of the wind; it appears clearly from the reports that the sounds were loudest on the side of Krakatoa whither the wind blew, and the fine ash particles were blown. But this does not yet explain the fact that the sound was sometimes better heard in places that were further off than in those that were nearer when those places lay in the same direction from Krakatoa, such as, for example, Anjer, Serang, and Batavia. This phenomenon is to be ascribed solely to the great quantity of ash particles which were present in the lower atmosphere. If one assumes for example the presence of a thick cloud of ashes between Krakatoa and Anjer, this would act on the sound waves like a thick soft cushion; along and above such an ash cloud the sound may be propelled very easily to further removed places, for instance Batavia, whereas at Anjer, close behind the ash cloud, no sounds or only faint ones would be heard. Cther explanations, such as by the interference of sound, seem to me less probable though not entirely impos. sible.

Besides these sound vibrations, very long air waves were formed during the explosions, which did not manifest themselves by any sound, but had nevertheless an important effect. The most rapid of these vibrations communicated themselves to the buildings and walls of rooms, so that objects which hung on the walls or from the ceiling were set in motion. Thus at Batavia and at Buitenzorg, a distance of 150 kilometres from Krakatoa, the doors and windows began to rattle, clocks stood still, ornaments on cabinets fell down, and hanging lamps were 
thrown out of their fastenings, and fell shattered to the ground with their chimneys and globes.

But not only at this distance was the air vibration perceptible. At Batoe-Radja in Palembang (250 kilometres from Krakatoa) rents appeared in the pradjoerit's barracks at three o'clock in the night; even at Palembang, 350 kilometres from Krakatoa, several Government buildings had to be immediately vacated as a crash was feared; and even in the Alkmaar country in Pasoeroean, 830 kilometres from Krakatoa, the walls were rent in the house of the administrator and the machinist. All this was caused by air vibrations, not by earthquakes, for it is a remarkable fact that these have nowhere been observed with certainty in this eruption.

Finally in the most violent explosions, air waves of an astonishing length were formed. As the Meteorological Institute at Batavia no longer possesses a self-registering barometer, those waves would have passed unobserved at Batavia, had they not fortunately been recorded by the indicator of the gas-works. This apparatus is selfregistering, and continually marks on a paper, wound round a turning cylinder, the pressure of the gas. As the large gasometer was set in motion on August 26 and 27 by the pressure of the air waves, these oscillations were marked by the indicator, and the line of pressure shows that day, not the normal curves, but a number of sharp points. As hour lines are marked on the paper, the time at which these oscillations occured can be accurately fixed, and if the time be deducted which the wave requires to travel from Krakatoa to Batavia, the moment is also known when the wave was formed, and the explosion took place (omitting a correction for the time which elapses between the moment of pressure on the gasometer and the moment this is recorded by the indicator, a lapse of time which is unfortunately not exactly known). The barometer experiments in Europe and America show that those large air waves possess almost as great a velocity as sound, from which it follows that they require seven minutes to travel the distance between Krakatoa and Batavia.

I have concluded from this that the most violent explosions took place at the following hours :-August 27, 5h. $35 \mathrm{~m}$., 6h. $5 \mathrm{~mm}$., 10h. $5 \mathrm{~m}$., and roh. $55 \mathrm{~m}$., Batavia time. By far the most violent of these four was the explosion of $10 h .5 \mathrm{~m}$. Then also an air wave was propelled from Krakatoa which spread in a circular form round this point as pole along the surface of the earth, and travelled no less than three and a quarter times round the whole circumference of the earth. The velocity was, as already observed, about the same as that of sound, although these were waves of a gigantic length (the length of the lowest sound waves being about 20 metres, that of the Krakatoa air wave more than a million metres).

The eruptions, which took place at first above the sea, probably became submarine about ten o'clock on August 27. Before that time only more or less damp ashes were ejected, after that also a large quantity of mud or mire, being volanic sand mixed with sea-water. The giving way of the northern part of the mountain must have preceded these submarine eruptions, as appeared from the time at which the large tide wave, which probably originated through this subsidence, overflowed the Vlakken Hoek. This catastrophe caused a great change in the group of islands of Krakatoa. To the north-west of Krakatoa lies Verlaten Island, to the north-east Long Island, and west of the latter lies the Poolsche Hoedje. This small island has disappeared, the two others still exist, and are even larger than before, through the ejected substances which have settled on and around the island; but the greatest change has been undergone by Krakatoa itself. The whole northern part with the craters Perboewatan and Danan, and half of the peak have sunk in the depths. There only remains the southern part of the peak, which has been cut in two from the very top, and forms on the north side a magnificent precipitous cliff more than 800 metres high. Through the downfall therefore a volcano rupture has been formed which is probably unique in the world. A coloured drawing of this remarkable rock will be added to the large report.

The size of Krakatoa was formerly $33^{\frac{1}{2}}$ square kilometres; of that 23 square kilometres have subsided, and $10 \frac{1}{2}$ square kilometres remain extant. But on the south and south-west side the island has been increased by a large ring of volcanic products, so that the size of New Krakatoa is now, according to our survey, $15 \frac{1}{3}$ square kilometres. The size of Long Island was formerly $2^{\circ} 9$ and is now 3.2 square kilometres. Verlaten Island has become much larger; it was formerly 3.7 and is now II.8 square kilometres in size. Of the Poolsche Hoedje nothing remains.

In the place where the fallen part of Krakatoa once stood there is now everywhere deep sea, generally 200 , in some places even more than 300 metres deep. It is remarkable that in the midst of this deep sea a rock has remained which rises about 5 metres above its surface. Close to this rock, which is certainly not larger than 10 metres square, the sea is more than 200 metres deep. It is like a gigantic club, which Krakatoa lifts defiantly out of the sea.

The volcanic products of the preceding year consist almost exclusively, as we have already said, of pumicestone ; only here and there among the pale gray material a solitary piece of darker coloured steatite or a vitreous piece of obsidian appears. Although the stone masses in the crater were doubtless liquid, a stream of lava could nowhere pour down, because everything was shot out of the crater in larger and smaller pieces, and generally in powder.

The chemical composition of the ejected substances is not yet sufficiently known, but from the analyses that have hitherto been made it would appear that all the substances do not contain the same quantity of silica; probably that the large pieces floating on the top of the molten mass were somewhat more acid than the lava that lay deeper in the crater and was ejected as powder. The ashes collected by myself at Buitenzorg contained, according to the analysis made at Batavia, 60 per cent ; a piece of pumicestone, collected on the Island Calmeyer, 68 per cent.; a small piece of obsidian from Krakatoa over 68 per cent. ; and fine yellow ashes from the east coast of Krakatoa even 70 per cent. of silica. There was found moreover alumina 14 to 16 per cent., protoxide of iron 6 per cent., chalk 4 per cent., soda 4 to 6 per cent., and a little magnesia.

In the microscopic examination of the ashes collected at Buitenzorg there was found-(I) glass in innumerable irregular fractured particles, generally completely permeated with vacuoles round or oval ; in some particles the glass threads are bent. Those glass particles, microscopic pieces of pumice-stone, are always present in large abundance. (2) felspar, very fresh and clear, sometimes with distinct polysynthetic twin lines, generally, however, in single crystals; all seems to be plagioclase, as the analysis shows no potash. As inclusions in the felspar are found glass, apatite, augite, and magnetite. (3) pyroxene, partly green and then extinguishing obliquely, therefore monoclinic augite, partly coloured brown, and then, as it appears, extinguishing in parallel lines; it is not yet quite certain whether these last brown augites, which are present in much larger quantities than the green ones, belong to a rhombic pyroxene (bronzite or hypersthene), or are brown monoclinic augites which lie in the preparations on the orthopinacoid. This would be fortuitous; but if the orthopinacoid is much more developed in those crystals than the klinopinacoid, it is not surprising. I also believe I observed in one brown crystal oblique extinction, while sometimes transitions from brown to green tints occur. Inclusions are glass, apatite, magnetite. (4) magnetite in grains and oc- 
tahedra, as the oldest component part. The quantity of magnetite decreases in the ashes in proportion as they fell further from Krakatoa.

If the molten mass had slowly cooled, an ordinary augite-andesite or andesite-steatite (with rhombic pyroxene), would have originated.

The thickness of the ejected substances diminishes on the whole as the distance from Krakatoa increases; the coarser material fell principally within a circle, with a radius of 15 kilometres drawn round Krakatoa, although pieces of the size of a fist were still thrown at a distance of 40 kilometres. Within the circle of 15 kilometres' radius the thickness of the layers of volcanic substances is 20 to 40 metres. At the back of the Island of Krakatoa, the thickness of the ash mountains at the base is in some places even 60 to 80 metres, but diminishes in thickness upwards, so that, in the deep clefts, which have already been hollowed out by the water, the old surface of the mountain and the fallen trees appear.

The thick layers of ashes were cooled at the top at the time of my visit, but were still very hot below, so that in the deep ravines hot water and steam appeared everywhere; also at Verlaten Island, Long Island, the Islands Steers and Calmeyer, and even at Sebesi, steam was seen to escape here and there. At Krakatoa there are, besides, stems of trees which have been carbonised by the hot ashes and continue to smoulder close to the fracture, where the air can penetrate, so that at night a little fireglow and smoke may be observed. These small fires specially gave rise to the report that Krakatoa was still active.

The ascent of the mountain from behind, on the pumicestone elevations, is difficult, but possible ; the innumerable crevices, into which one must constantly descend, make the climbing up in the great heat and the total want of shade very fatiguing. The ascent may be made from the north-west, close along the rupture till about 20 metres from the top, which, according to our measurements, lies 831 metres above the sea; the surroundings of the top are rent and constantly crumbling away.

Between Krakatoa and Sebesi there is a large quantity of ashes and pumice-stone which has filled up that entire part of the sea, and projects in two places above the surface. To these two points the names of Steers Island and Calmeyer Island have been given. They do not rise more than a few metres above the sea, have much to suffer from the beating of the waves as they only consist of loose material, and will soon be washed away. The sixteen small craters between Sebesi and Krakatoa, reduced in later reports to six or four, have never existed. The smoking volcanic accumulations have been mistaken for active craters which, at first, from a distance was not unlikely to happen.

The finer ashes were blown eastward (east-south-east), to near Bandoeng (250 kilometres from Krakatoa), in a north-north-west direction to Singapore and Bancalis, respectively 835 and 915 kilometres from Krakatoa, in a south-west direction as far as Kokos Island (Keeling Island), I,200 kilometres from Krakatoa; how far the ashes were projected west, north, and south is unknown; the surface comprises at least 750 ,000 square kilometres, that is, almost as large an area as Sweden and Norway, larger than the Austro-Hungarian Empire, also larger than the German Empire with Denmark (including Iceland), the Netherlands, and Belgium together, and twenty-one times the size of the Netherlands.

Evidently the prevailing wind-currents, i.e. south-east and north-east, have carried the particles along, which causes the outline of the surface covered with ashes to be irregularly curved.

Finer particles still have fallen even beyond this line into the sea, as appears from reports of ships; and the finest of all, mixed with a quantity of vapour, remained a long time floating in the upper air-currents, and, pro- pelled by the wind, have made a journey round the world. The vapour was condensed to water, and froze in the cold currents; the refraction through the innumerable ice crystals caused the beautiful dark red glow which was observed the last months in so many places in Asia, Africa, Europe, and America; while the ash particles partly obscured the sunlight, or gave the sun blue and green tints at its rise and setting.

If one considers that the volume of the solid ejected substances already amounts to several cubic kilometres, and that the volume of ejected gas substances was perhaps hundreds of times as large, the hypothesis of a cosmic ice cloud to explain the air phenomena seems to me quite superfluous.

That the ash particles, as a matter of fact, were carried very far in the upper air-currents, has already appeared from snow which fell in Spain, and rain in the Netherm lands, in which the same components were found as in the ashes of Krakatoa; and that the particles must moreover have been projected very high at the last eruption may be concluded from the report that, on the 2oth May, during one of the first eruptions, the steam cloud-according to the measurements taken on board of the German man-of-war, Elisabeth, which left Anjer that morning at nine o'clock--must have reached a height of at least 11,000 metres. During the much more violent explosions of August 26 and 27, the height, if the above report may be relied on, may very well have reached 15 to 20 kilometres.

I found that on calculating as accurately as possible the quantity of ejected solid substances, they reached 18 cubic kilometres. In doubtful cases the lowest figure was always selected, so that is kilometres may be too low, but not too high, a computation. The possible margin amounts in my estimation to not more than 2 or 3 cubic kilometres.

However large a quantity this may be, it does not nearly reach that which the Tombora produced in 1815 , and which Junghuhn estimates at 317 cubic kilometres; this computation, however, rests on but few data, so that in my opinion a quantity of 150 to 200 cubic kilometres will come nearer the truth. But even in that case the number is eight to eleven times larger than ours, which is not astonishing, as at that time at Madura, a distance of more than 500 kilometres from the Tombora, the sun was totally obscured for three days, whereas the darkness here only lasted a few hours.

Of these 18 cubic kilometres, which represent a weight of more than $36 \times 10^{12}$ kilogrammes, no less than 12 cubic kilometres, or two-thirds of the whole ejected quantity lies within the circle with a radius of 15 kilometres drawn round Krakatoa. As the sea between Krakatoa and Sebesi was not deeper than 36 metres, and the thickness of the volcanic ejections amounts to almost the same, the navigation there has become quite impossible. A little further the thickness diminishes considerably. From 15 to $22 \frac{1}{2}$ kilometres from Krakatoa, the average thickness amounts to no more than $I$ to $I \frac{1}{2}$ kilometres; within this ring lies Sebesi, which now only presents a heap of ashes, with a few projecting stumps of trees; nothing here remains of the four populated kampoengs which formerly stood on the plain opposite the small island Mengoenang (Huisman's Island), all has been washed away, and is covered with a layer of ashes I metre thick. From $22 \frac{1}{2}$ to 40 kilometres, the average thickness of the ashes amounts to $0^{\prime} 3$ metre, then to 50 kilometres $0^{\prime} 2$ metre. At a still greater distance from Krakatoa the thickness speedily diminishes to $2, \mathrm{I}$, and half a centimetre, but the finer the ashes become the more the direction of the wind is perceptible. An "ash map" will be added to the detailed report.

One more very remarkable phenomenon during the eruption was the formation of powerful sea waves, which flowed over the low-lying coast districts of the Straits of 
Sunda, and destroyed a number of kampoengs and more than 35,000 lives.

There is much uncertainty about the time at which these waves originated, and this is not surprising. The number of Europeans who witnessed the catastrophe on the coast places in the Sunda Straits and on board ships was but small; besides, most of them were in a state of great alarm, so that observations with a timepiece were exceptional. Most of the estimates of time were no more than a rough calculation, which, especially after the darkness set in, were not very trustworthy. This explains what came under my notice, that a time computation of the same event in the same place by two different people showed a discrepancy of an hour and a half.

Besides, a remarkable fact must be taken into account, namely, that the largest wave, the only one which spread great distances along the north coast of Java and to the south-west, and which surpassed all other waves by far in height, was almost seen nowhere; at Tjiringin alone this wave was seen to approach before the darkness began, and this was about ten o'clock on the morning of the 27th. Anjer was already destroyed at 6 a.m., and then abandoned At Telok Betong, and in the lighthouses on the Vlakken Foek, and at Java's First Point, the wave was not seen because it was pitch dark. Even in the lighthouse, 40 metres above the sea on Java's First Point, nothing was seen of the wave, and the destruction of the coast country was only discovered the next morning when it became light.

As the great darkness at Bantam set in soon after the great detonation of Ioh. $5 \mathrm{~m}$.- - the same explosion which gave rise to the great air wave--and as the wave had only time, before the darkness set in, to reach the neighbouring Tjiringin, which lies 47 kilometres from Krakatoa, this tide wave cannot have arisen much before $9 \mathrm{~h} .5 \mathrm{om}$. or $9 \mathrm{~h} .55 \mathrm{~m}$. At the Vlakken Hoek, ro3 kilometres from Krakatoa, it appeared at about Ioh. $30 \mathrm{~m}$., which agrees with our time computation, if it be taken into accoun that the velocity of the waves towards the Vlakken Hoek must have been greater on account of the greater depth of the sea than towards 'Tjiringin.

It is very probable that shortly before ten o'clock a subsidence of the hollow crater walls of one or both of the active craters took place, that through this the water gained access in large quantities, and that then half of the peak, which had been previously undermined and fractured by the eruptions, also disappeared in the depths. The cause of the great wave motion must no doubt be sought for in the subsidence of the peak. Of the northern part of the island, after the many eruptions, not much more than a hollow shell can have remained, the subsidence of which could not have caused waves of great importance; nor could the rush of the water produce great waves, but rather a suction towards Krakatoa, and this may be the cause of the water on the coast first retreating in various places before the great flood advanced.

The peak itself, however, was still massive, and I have calculated that the part which fell of this mountain alone, without Danan and Perboewatan, possessed a volume of at least I cubic kilometre. If this cubic kilometre be suddenly plunged into the sea, the same quantity of water must be displaced, which must give rise to a circular wave round Krakatoa.

There have been, however, other smaller waves: one as early as Sunday evening, August 26, at $5 \mathrm{~h}$. or 5h. 3om., two more in the night, and on Monday morning at $6 \mathrm{~h}$. a wave which destroyed Anjer. It is difficult to account for the small waves by assuming that parts of the mountain gave way, because, if so, probably the sea would have gained access also, and mud eruptions would have occurred much sooner, unless it be supposed that mud was ejected, but nowhere far enough to reach inhabited places, which is not quite impossible.
If no subsidences of the mountain had yet taken place, there only remains the assumption that these waves were caused by the enormous masses of ejected matter falling into the sea. As has been said above, 12 cubic kilometres of stones and ashes are lying close round Krakatoa; this quantity has been thrown there from May 20, but certainly, for the greater part, during the violent explosions of August 26 and 27. Assuming that, for instance, about I cubic kilometre of these substances was thrown into the sea at a time, waves must of course have been the result, which, as I have calculated, must have reached a considerable height.

The large wave of ten o'clock specially ran up a great height against the precipitous cliffs of the Sunda Straits, according to our measurements as follows:- -15 metres up the lighthouse at the Vlakken Hoek; at Beneawang (Semangka), uncertain; at Telok Betong, before the house of the Resident, 22 metres; at the Apenberg (Goenoeng Koenjit), 24 metres; at Kalianda, up a sloping plain, 24 metres; on the south side of Thwart the Way, \pm 35 metres (not measured); on the south side of Toppershoedje, 30 , on the north side, 24 metres; at Merak itself the height cannot be ascertained with certainty, the old house of the engineer stood only 14 metres above the sea; about 2 kilometres south of Merak, 35 metres ; north of Anjer, on the coast opposite Brabandshoedje, 36 metres. The height, therefore, varies everywhere, and depends on the situation of the places, their distance from Krakatoa, their being more or less sheltered, and the steepness of the coast. At Sebesi there is no trace left of the tide wave, as everything is thickly covered with ashes, which fell after the wave. At Seboekoe the height amounts from 25 to 30 metres, but no measurement was taken.

The big wave which was propelled from Krakatoa at about $9 \mathrm{~h}$. 5om. spread over great distances, among others as far as Ceylon, Aden, Mauritius, Port Elizabeth in South Africa, and even to the coast of France. The velocity of the waves varies greatly, of course, since it increases with the depth of the sea; I shall not be able to give a detailed summary till the tables of all the self-registering tide apparatus shall have been collected. For the Indian Archipelago, and a few points beyond, I found the following numbers:-

\section{Places}

Island Noordwachter

Tandjong-Priok (Batavia)

Undeepwater Island

Dendang (Billiton)

Tandjong-Pandan (Billiton)

Tjilamaja (Krawang)

Oedjoeng Pangka (near Soerabaja)

Pasar Manna (Benkoelen)

Padang.

Mauritius (Port Louis)...

Port Elizabeth ...

In our Archipelago the velocity is small, owing to the shallowness of the sea, but in the deep sea, on the route to Mauritius and the Cape, it increases considerably, i.e. amounts to more than 300 knots an hour, a velocity which is alone to be compared to that of the lunar tide wave and the earthquake waves of Simoda, in Japan, of December 23, I 854, and of Tacna, in Peru, of August I3, I 868.

From the velocity of the wave the average depth of the sea between the places along its path can be determined; I have put together in the foregoing table those various degrees of velocity, but they can only be trusted when the height of the wave is small with respect to the depth of the sea, which in our Archipelago is not strictly the case. However the numbers agree pretty well with the sea-chart. In the time computation of Mauritius there appears to be a mistake, as the average depth cannot be so different from that of Port Elizabeth.

After these terrible events Krakatoa slowly calmed 
down, not however without having still violently roared in the evening and night of August 27 to 28. The detonations were scarcely less strong at Buitenzorg from ten to one o'clock than in the morning. But after the 28th nothing more was heard of the mountain. The tidal registrations at Tandjong Priok exhibit still a few small oscillations till August 30 at twelve o'clock in the day, but after that the condition of the water also became normal. Notwithstanding this I found that there must have been a serious eruption a considerable time after August 28, and shortly before I visited the island.

On October I I I left Batavia with my staff, and after having visited various points in the Straits of Sunda, arrived at Calmeyer on the 15 th. We stopped a few hours in order to survey the island, which is a perfectly bare bank of pumicestone, divided into seven parts by encroachments of the sea ; the temperature was $42^{\circ}$ Celsius, a heat which almost stupefied us. Here already my attention was drawn to the fact that the white or pale gray pumice-sand was covered by a 0.2 metre thick layer of darker coloured very fine ash, which exhibited numerous fissures on the surface, produced in the process of drying, and therefore had probably fallen there as wet mud. I did not, however, then attach any special importance to this phenomenon.

On the ${ }^{6} \mathrm{fth} I$ arrived at Krakatoa and remained there till the 18 th. When in surveying the mountain on the I 7 th we had climbed to the top, and began the steep descent on the south side, I observed with astonishment that on the ordinary gray pumice-stone material two black streaks were visible, which began 600 metres above the sea, therefore about 200 metres lower than the top, and could be traced in a tolerably straight line over a length of 1300 metres till 100 metres above the sea. These black streaks proved to be two mud streams, which had flowed down the slope of the mountain and had covered the white pumice-stone to the thickness on an average of 0.2 to 0.3 metre and a breadth of $I$ to 5 metres. The most remarkable fact was, however, that these mud streams were not only traced down the back of the mountain but had also flowed into the deep ravines of pumice-stone material, as can be distinctly seen. Therefore those mud streams did not arrive there till the crevices in the pumice-sand already existed, and as several weeks must have been required for the water to hollow out these ravines the mud eruption cannot immediately have followed the eruptions of August. The very fine dark gray mud was still damp at the time of my visit, and could be kneaded with the hand, which also proves that the streams were of recent origin.

In this eruption very curious objects were ejected, i.e. very smooth, round balls resembling marbles, to the size of $I_{2}^{\frac{1}{2}}$ to 6 centimetres in diameter. They are full of acids, they contain 55 per cent. carbonate of lime, 26 per cent. silica, i i per cent. alumina, and 5 per cent. water. These calcareous lumps of marl must be derived from layers of marl which exist at the bottom of the Straits of Sunda in the neighbourhood of Krakatoa, and the slime or dust of which has been shot out of the crater in a rapid revolving motion. The balls, which are rare, are never found inside but only on the top of the pumice-stone dust, generally half sunk in the sand; they evidently belong to the last ejections. Whether the mud streams also contain lime I have not been able to ascertain, as a piece brought as a sample has unfortunately been lost.

The last mud eruption, which must have been very important, since on Calmeyer, I 2 kilometres from Krakatoa the upper black layer is 0.2 metre thick, and the mud must have been thrown over the top, which is 830 metres high, to the back of the mountain, whence it poured down, probably took place only six days before my arrival, namely on October Io, at about $9 \mathrm{~h}$. $30 \mathrm{~m}$. in the evening, because on that evening at about ten o'clock a considerable tide wave arrived at Tjikawoeng in Welkomstbaai
(Welcome Bay), the only tide wave which was observed since August 28. A rumbling sound in the direction of Krakatoa was then heard in that place, as well as a little more northward at Soemoer. The wave overflowed the shore to a distance of 75 metres beyond the tide-mark at Tjikawoeng, but has not been observed at other points of the coast, as the devastated coast country was not yet inhabited and was quite abandoned at night. We find in this another proof that the falling down of large quantities of ejected substances round Krakatoa suffices to form important waves in the Straits of Sunda.

The eruption on October Io seems to have been the last. But this eruption was scarcely noticed, and it is therefore possible that subsequent feebler volcanic actions may have remained quite unobserved. When I visited Krakatoa there was nowhere any sign of activity. On October I 8 we left Krakatoa, and we arrived on the evening of the Igth at Vlakken Hoek, where nothing was noticcable. It is not likely, therefore, that the rumbling sounds which were heard that evening at Tangerang and Mauk coming from the west should have proceeded from Krakatoa. It would, however, be very interesting to visit Krakatoa once more in order to be able to trace whether any more changes have taien place since October i 8 .

Though there is no fear of any serious eruption of Krakatoa after the terrific activity of the volcano and the subsidence of the greater part of the island, still much that is intcresting may be learnt yet from less important subsequent volcanic actions, as we see in the instance of the lumps of marl.

With the detailed report a large map of Krakatoa will appear, as well as maps of Calmeyer, the devastated parts of Merak, Java's First Point, Sebesi, Seboekoe, Telok Betong, and Kalianda; moreover tables indicating the pressure at the gas-works at Batavia, and of the selfregistering tidal apparatus at Tandjong Priok and at Soerabaja; a small "ash map" and other supplements, and finally a few coloured drawings of Krakatoa and the devastated districts, where in a few moments tens of thousands of people lost their lives on the memorable 27 th of August, I883.

Buitenzorg, February 19, 1884

\section{THE LATE MONSIEUR DUMAS}

$A \mathrm{~T}$ the funeral of this eminent chemist addresses were given by the representatives of various official bodies. From these we subjoin the following extracts, affording as they do an idea of the estimation in which $M$. Dumas was held by his contemporaries, and of the position to which he is entitled in the science of the present century.

M. le Comte d'Haussonville, Director of the French Academy, said :-

"Who was more worthy than Jean Baptiste Dumas of the high distinctions conferred on him by the Academy of Sciences! By us he was welcomed at a time when his name already ranked amongst the most illustrious of our times, when he had already been hailed as a master by associates destined soon to become masters in their turn. To their authoritative voice, rather than to me, must belong the duty of recording the signal services rendered to science by our regretted colleague, whose mortal remains lie at our feet. They will tell you with a fulness far beyond my power how, under the first inspiration of his soul, he understood how to vary his experiments and verify his assumptions. And with what supreme delight, says one of our confrères, who had the honour to receive him into the Academy, he pierced with eagle-eye into the depths of the divine laboratory, beyond which there is naught but the infinite, the unfathomable, the unapproachable! Speaking of his own work, he himself thus expresses himself :--'Above the sphere of phenomena which we study, and where such a vast field of discovery still 